\title{
IDENTIFIKASI JENIS VEGETASI DOMINAN DI AREAL BEKAS KEBUN DAN KEBUN DI KAMPUNG AYAMBORI MANOKWARI \\ (Identifying Dominant Vegetation In The Plantation Area And Former Farmland As The Indicator Of Soil Fertality At Ayambori Village - Manokwari)
}

\author{
Heru Joko Budirianto ${ }^{1}$, Fajar R Sianipar, Mercy Arobaya \\ Email : herujokobudirianto@gmail.com
}

1. Department of Biology, Faculty of Mathematics and Natural Sciences, University of Papua Jl. Tugu Jepang Amban - Manokwari, PO Box 98 314, E-mail:herujokobudirianto@gmail.com

\begin{abstract}
The purpose of this study is to identify types of dominant vegetations in the plantation area and former farmland as indicator of soil fertility. Vegetation plays an important role to provide soil fertilities. Certain types, growing in the former farmland can possibly indicate soil fertilities both in the plantation area and former farmland. Aspect of the fertilities likely influences number of vegetative types and diversity of species.

Measured vegetation is used to comparing species composition and its diversities. The former plantation that is taken up as sample has been used for 5 year. Identification of the type was carried out by using vegetative analysis. The valuable index was calculated to determine extensively the role of the dominant types from seeding and wooded phase. There are four different plot sizes. 20×20 meter is utilized purposively for wooded phase, $10 \times 10$ meter is pole, $5 \times 5$ is used as stake phase and $2 \times 2$ meter is made for seeding phase. The species which has important role for the soil fertilities are indentified through exploring various references and the result of interview from local society

The finding reveals that vegetative composition in the former farmland which has been used for 5 year consists of three phases, including seeding, stake and pole. Totally, the types are 30 species under each phase. 23 types are in the seeding, 19 types contribute for pole and 6 types are resulted in the wooded phase. The dominant type of seedling phase is Lunasia amara, Piper aduncum is gotten in the stake phase, and the pole one is Mallotus philippensis. However, differently the plantation area carried out 39 species in the seeding phase, sapling phases has 36 species, pole phase carries out 16 species and 17 species is in the wooden phase. The dominant types is in the seeding and stake phase is Nephelium lappaceum, Lansium domesticum is pole phase, and Durio zibenthinus is resulted in the wooded phase
\end{abstract}

Keywords: Dominant Vegetation, Former Farmland, Plantation Area, Kampung Ayambori

\section{PENDAHULUAN}

Jenis pohon dan vegetasi tertentu memiliki serasah yang juga turut menyumbangkan kesuburan tanah di perkebunan. Unsurunsur serasah yang dihasilkannya seperti daun, ranting, bunga, dan buah sangat mempengaruhi jenis ketersediaan hara makro maupun mikro dalam tanah (Umam 2011). Unsur-unsur tersebut secara langsung juga mempengaruhi pasokan air saat kejadian hujan, dan turut membentuk 
kelembaban pada tanah yang menunjang bagi kehidupan mikroorganisme tanah untuk proses dekomposisi.

Aspek kesuburan tanah perkebunan dipengaruhi oleh sifat fisika dan kimia tanah yang mutlak ada sebagai salah satu indikator kesuburan. Sifat fisis tanah dipengaruhi oleh aspek kimia yang ada dalam tanah. Begitu juga sebaliknya, sifat kimia tanah sangat ditentukan oleh keberadaan vegetasi yang turut mempengaruhi sifat fisis tanah (Yamani 2010). Kesuburan tanah ditentukan oleh ketersediaan unsur hara yang cukup dan berimbang, kondisi tata air dan udara tanah yang optimal, dan kondisi mikrobia tanah yang baik (Arijani 2006). Sedangkan kurangnya aspek kesuburan tanah perkebunan dipengaruhi oleh panen, fiksasi, pelindian, kecepatan penyerapan unsur hara tanah oleh vegetasi yang tumbuh di atasnya, Infiltrasi tanah yang kurang baik, dan meningkatnya erosi akibat kurangnya intersepsi air hujan oleh vegetasi (Kurniasari 2009).

$$
\text { Jenis vegetasi dominan, }
$$
mempengaruhi keberadaan unsur hara makro maupun mikro. Arifin (2011) menyatakan, unsur hara di lahan hutan yang didominasi oleh pohon Matoa (Pometia senencen) menyumbangkan bahan organik dan menaikkan nilai kualitas tanah tertinggi di tanah entisol. Lain halnya dengan tanah yang ditanami jenis Kelapa Sawit (Elaeis guineensis, Jacq) mempengaruhi nilai $\mathrm{pH}$ tanah dan nilai $\mathrm{C} / \mathrm{N}$ sangat rendah, kandungan $\mathrm{Ca}, \mathrm{K}$, dan $\mathrm{Na}$ tergolong rendah, sedangkan untuk unsur $\mathrm{P}$ dan $\mathrm{Mg}$ tergolong tinggi (Tambunan 2008). Tanaman yang kurang mampu menahan erosi dapat mengakibatkan kurangnya tanah pada lapisan atas. Kehilangan tanah hingga 60 $\mathrm{cm}$ akibat erosi, dapat menurunkan hasil panenan kedelai sebesar $48-88 \%$. Perlakuan yang berbeda dalam menanam jenis sayuran di daerah kelerengan mempengaruhi keberadaan hara dalam tanah. Tanaman sayur yang ditanam berlawanan dengan arah kelerengan, mampu menekan kehilangan unsur hara esensial. Perlakuan penanaman sayuran di atas guludan yang berlawanan arah lereng, mampu menekan kehilangan unsur $\mathrm{N}$ sebesar 55\%, $\mathrm{P}$ total $70 \%$, untuk ketersediaan $\mathrm{K}$ dan $\mathrm{C}$-Organik sebesar $68 \%$, dibandingkan dengan penanaman yang searah dengan lereng (Bernas dan Sulistyani 2003).

Masyarakat di kampung Ayambori memiliki lokasi kebun yang diberakan dan kebun aktif yang saat ini digunakan untuk bercocok tanam. Jenis vegetasi yang ada di kedua lokasi tersebut tidak sama. 
Komposisi jenis di kebun yang diberakan mengalami perubahan akibat suksesi sekunder. Demikian pula perlakuan terhadap vegetasi di lokasi kebun aktif tidak sama. Masyarakat akan melakukan pemilihan jenis yang ditanam serta pengolahan tanah sebagai upaya mengoptimalkan fungsi tanah dan mempertahankan kesuburan. Hal ini berpengaruh pada unsur kesuburan tanah di kedua lokasi. Olehnya perlu diketahui, sejauhmana dampak vegetasi dominan terhadap kesuburan tanah di kedua lokasi perkebunan yang berbeda. Tujuan Penelitian ini adalah mengidentifikasi jenis vegetasi dominan di areal kebun dan bekas kebun untuk indikator kesuburan tanah di kampung Ayambori Manokwari

\section{METODE}

Penelitian dilakukan pada bulan Februari-Juni 2016, bertempat di areal perkebunan masyarakat yang diberakan dan kebun aktif Kampung Ayambori Kabupaten Manokwari. Identifikasi jenis dilakukan langsung di lapang dengan menggunakan jasa pengenal jenis. Penelitian dilakukan berdasarkan teknik observasi, dan wawancara. Observasi dilakukan dengan menentukan lokasi kebun yang dijadikan tempat penelitian. Penentuan lokasi dilakukan secara purposive sampling. Lokasi yang diamati ada 2 tempat, lokasi kebun yang diberakan dan lokasi kebun aktif. Lokasi tersebut diamati dengan tujuan untuk membandingkan komposisi jenis yang ditanam oleh masyarakat dan membandingkan tingkat kesuburan tanahnya. Plot pengamatan dibuat dengan ukuran $20 \times 20 \mathrm{~m}^{2}$ atau dengan luas 400 $\mathrm{m}^{2}$ untuk fase pohon. Dalam plot tersebut dibuat sub plot dengan ukuran $10 \times 10 \mathrm{~m}$ untuk fase tiang, 5 × $5 \mathrm{~m}$ untuk pancang, dan $2 \times 2$ m untuk tingkat semai. Pohonpohon yang berdiamater batang setinggi dada atau pada ketinggian $1,3 \mathrm{~m}$ di atas tanah, diukur menggunakan metode kuadrat. Parameter yang diukur antara lain jumlah dan nama jenis, nilai kerapatan, dominasi jenis, frekwensi jenis, indeks nilai penting jenis tumbuhan tingkat pohon dan tumbuhan bawah, serta keanekaragaman jenis.

Data yang dikumpulkan berupa data primer dan sekunder kemudian dianalisis secara deskriptif, kuantitatif dan tabulasi. Data komposisi jenis pohon di lokasi yang telah diberakan dan kebun aktif masyarakat Kampung Ayambori dianalisis menggunakan analisis vegetasi dengan metode kuadrat. Peranan jenis pohon dapat diketahui dengan menghitung Nilai Penting Jenis dengan persamaan: 


$$
\begin{aligned}
& \text { Kerapatan (Mutlak) Jenis }=\frac{\text { Jumlah Pohon per Jenis }}{\text { Luas Plot Contoh }} \text { pohon } / \text { ha } \\
& \text { Kerapatan Relatif Jenis }=\frac{\text { Kerapatan Mutlak Jenis }}{\text { Jumlah Kerapatan Jenis }} \times 100 \% \\
& \text { Dominasi (Mutlak) Jenis }=\frac{\text { Luas Bidang Dasar Jenis }}{\text { Luas Areal Plot }} \mathrm{m}^{2} / \mathrm{ha} \\
& \text { Dominasi Relatif Jenis }=\frac{\text { Dominasi }(\text { Mutlak) Jenis }}{\text { Jumlah Dominasi }(\text { Mutlak)Seluruh Jenis }} \times 100 \% \\
& \text { Frekwensi (Mutlak) Jenis }=\frac{\text { Jumlah Plot yang diduduki Jenis }}{\text { Jumlah Plot Seluruhnya }} \\
& \text { Frekwensi Relatif Jenis }=\frac{\text { Frekwensi (Mutlak) Jenis }}{\text { Jumlah Frekwensi (Mutlak)Seluruh Jenis }} \times 100 \%
\end{aligned}
$$

Nilai Penting Jenis $=$ Kerapatan Relatif Jenis + Frekwensi Relatif Jenis (untuk Fase semai dan Pancang)

Nilai Penting Jenis $=$ Kerapatan Relatif Jenis + Dominasi Relatif Jenis + Frekwensi Relatif Jenis (untuk Fase Tiang dan Pohon)

Keanekaragaman jenis pohon dan vegetasi lainnya dihitung menggunakan indeks ShanonWiener dengan persamaan $\mathrm{H}=-\sum(\mathrm{Pi} \ln \mathrm{Pi})$

Dimana $\mathrm{H}=$ indeks keragamanan

$$
\begin{aligned}
& \mathrm{Pi}=n \mathrm{i} / \mathrm{N} \\
& \mathrm{ni}=\text { jumlah individu jenis ke-i } \\
& \mathrm{N}=\text { Total Individu }
\end{aligned}
$$

\section{HASIL DAN PEMBAHASAN}

\section{Komposisi Vegetasi di Lahan Bera 5}

\section{Tahun}

Komposisi vegetasi di lahan Bera 5 tahun terdapat 3 Fase, antara lain fase semai, pancang, dan tiang. Jumlah Seluruh jenis pada lahan bera 5 tahun adalah 30 jenis. Adapun komposisi jenis dari masing-masing tingkatan terdiri dari tingkat semai 23 jenis, tingkat pancang 19 jenis, dan tingkat tiang 6 jenis.

Komposisi jenis tingkat Semai pada lahan bera 5 tahun dengan urutan 10 INP terbaik dapat dilihat pada Tabel 1. 
Tabel 1. Indeks Nilai Penting tingkat Semai pada Lahan Bera 5 Tahun

\begin{tabular}{rlrrr}
\hline No & \multicolumn{1}{c}{ Nama Jenis } & KR & FR & INP \\
\hline 1. & Lunasia amara & $17.50 \%$ & $10.20 \%$ & $27.70 \%$ \\
\hline 2. & Premna corymbosa & $11.25 \%$ & $12.24 \%$ & $23.49 \%$ \\
\hline 3. & Piper aduncum & $10.00 \%$ & $10.20 \%$ & $20.20 \%$ \\
\hline 4. & Pometia pinnata & $8.75 \%$ & $10.20 \%$ & $18.95 \%$ \\
\hline 5. & Mallotus sp. & $7.50 \%$ & $8.16 \%$ & $15.66 \%$ \\
\hline 6. & Ficus septica & $6.25 \%$ & $8.16 \%$ & $14.41 \%$ \\
\hline 7. & Siphonodon celastrineus & $6.25 \%$ & $4.08 \%$ & $10.33 \%$ \\
\hline 8. & Spatiosthemon javaensis & $3.75 \%$ & $4.08 \%$ & $7.83 \%$ \\
\hline 9. & Pisonia cauliflora & $2.50 \%$ & $4.08 \%$ & $6.58 \%$ \\
\hline 10. & Macaranga aleutoides & $2.50 \%$ & $2.04 \%$ & $4.54 \%$ \\
\hline
\end{tabular}

Lunasia amara merupakan jenis dengan INP tertinggi $27.70 \%$. Jenis ini merupakan khas tanah berkarang. Penelitian yang dilakukan oleh Lekitoo et al (2013) dan Budirianto et al (2015) menyatakan bahwa jenis ini selalu ada dan menempati INP tertinggi. Jenis lain yang juga menjadi ciri khas daerah berkarang antara lain Pometia pinnata, Spatiostemon javaensis dan Palaquium amboinensis. Jenis yang memiliki INP $4.54 \%$ berjumlah 7 jenis, antara lain Alstonia scholaris, Gliricidia sepium, Maesa tetandra, Mallotus philippensis, Malotus rhizinoides, dan Palaquium amboinensis. Karakteristik tanah yang ada di Lahan Bera 5 tahun adalah berbatu, dan lapisan tanah tidak dalam. Tingkat semai memiliki jumlah jenis lebih banyak dibandingkan dengan fase pancang dan tiang. Jumlah tersebut sangat penting menunjang peningkatan kesuburan tanah dan mencegah terjadinya erosi saat hujan. Kunarso dan Azwar (2012) menyatakan bahwa peranan tumbuhan bawah seperti semai selain sebagai sumber keragaman hayati, juga berperan dalam menjaga unsur mikro serta mencegah tanah dari bahaya erosi dan menjaga kesuburan tanah.

Komposisi jenis maupun jumlah pada tingkat semai, dipengaruhi oleh usia lahan yang diberakan. Semakin muda suatu lahan bera, jumlah jenis dan individu masih sedikit. Jumlah Seluruh individu semua jenis di tingkat semai 80 individu. Indeks keragaman pada tingkat ini tergolong sedang yaitu 1.21.

Jumlah jenis pada tingkat pancang berjumlah 19 jenis, dengan total individu sebanyak 111 individu. Komposisi jenis tingkat Pancang pada lahan bera 5 tahun dapat dilihat pada Tabel 2. 
Tabel 2. Indeks Nilai Penting Jenis tingkat pancang di lahan Bera 5 Tahun

\begin{tabular}{rlrrr}
\hline No & \multicolumn{1}{c}{ Nama Jenis } & KR & FR & INP \\
\hline 1. & Piper aduncum & $26.13 \%$ & $12.00 \%$ & $38.13 \%$ \\
\hline 2. & Premna corymbosa & $12.61 \%$ & $12.00 \%$ & $24.61 \%$ \\
\hline 3. & Mallotus philippensis & $11.71 \%$ & $16.00 \%$ & $27.71 \%$ \\
\hline 4. & Gliricidia sepium & $10.81 \%$ & $6.00 \%$ & $16.81 \%$ \\
\hline 5. & Spathiostemon javensis & $8.11 \%$ & $8.00 \%$ & $16.11 \%$ \\
\hline 6. & Lunasia amara & $4.50 \%$ & $6.00 \%$ & $10.50 \%$ \\
\hline 7. & Mallotus rhizonoides & $4.50 \%$ & $6.00 \%$ & $10.50 \%$ \\
\hline 8. & Pisonia cauliflora & $4.50 \%$ & $4.00 \%$ & $8.50 \%$ \\
\hline 9. & Mallotus sp & $3.60 \%$ & $4.00 \%$ & $7.60 \%$ \\
\hline 10. & Maesa tetandra & $1.80 \%$ & $4.00 \%$ & $5.80 \%$ \\
\hline
\end{tabular}

Jenis Piper aduncum memiliki INP tertinggi disusul masing-masing Premna corymbosa, dan Mallotus philippensis. Jenis Spatiostemon javaensis dan Lunasia amara menempati urutan daftar INP 10 terbaik. Kemampuan 2 jenis tersebut beradaptasi dengan kondisi lingkungan tanah berkarang sangat baik. Lahan bera 5 tahun di kampung Ayambori mengalami pertumbuhan yang baik. Hal ini ditunjukkan dengan Jumlah individu pada fase pancang sebanyak 111 individu. Bertambahnya jumlah individu pada fase ini dapat meningkatkan substrat tanah yang berdampak pada bertambahnya jumlah individu dan keragamannya pada setiap fase. Indeks keragaman jenis pada tingkat pancang adalah 1.05 dengan Fase paling tinggi di lahan bera 5 tahun adalah Tiang. Pada tingkat ini kategori sedang. Fase pancang mengalami penambahan 6 jenis yang tidak terdapat pada fase semai. Jenis-jenis tersebut antara lain Casuarina rumphiiana, Ficus glabosa, Ficus variegate, Leea aculeacta, Mallotus sp2, dan Spatodea campanulata. Meningkatnya jenis pada fase pancang di lahan bera 5 tahun menunjukkan bahwa kondisi tanah di lahan bera ini mengalami perkembangan sifat substrat tanah yang dinamis. Hal ini sesuai dengan pendapat Kasim (2012) menyatakan bahwa selama proses suksesi sekunder, peningkatan keragaman jenis dapat mengubah perkembangan sifat substrat tanah. Kondisi ini sangat dibutuhkan untuk mengembalikan kesuburan tanah setelah diberakan.

jumlah keseluruhan jenisnya ada 6 jenis. Meskipun demikian, terdapat 1 jenis 
tambahan yang tidak terdapat pada tingkat semai dan pancang yaitu Artocarpus altilis. Peranan jenis yang ditunjukkan dengan INP dapat dilihat pada Tabel 3.

Tabel 3. Indeks Nilai Penting Jenis Tingkat Tiang di Lahan Bera 5 Tahun

\begin{tabular}{rlcccr}
\hline No & \multicolumn{1}{c}{ Nama Jenis } & KR & FR & DR & INP \\
\hline 1. & Mallotus philippensis & $53.85 \%$ & $54.55 \%$ & $48.46 \%$ & $156.85 \%$ \\
\hline 2. & Pometia pinnata & $15.38 \%$ & $9.09 \%$ & $21.59 \%$ & $46.07 \%$ \\
\hline 3. & Mallotus sp. & $7.69 \%$ & $9.09 \%$ & $10.05 \%$ & $26.83 \%$ \\
\hline 4. & Ficus sp. & $7.69 \%$ & $9.09 \%$ & $7.38 \%$ & $24.17 \%$ \\
\hline 5. & Macaranga aleuritoides & $7.69 \%$ & $9.09 \%$ & $7.38 \%$ & $24.17 \%$ \\
\hline 6. & Artocarpus altilis & $7.69 \%$ & $9.09 \%$ & $5.13 \%$ & $21.91 \%$ \\
\hline
\end{tabular}

Jenis dominan pada tingkat tiang adalah Mallotus philippensis dengan INP $156.85 \%$. Jenis-jenis lainnya seperti Pometia pinnata, Ficus sp, dan Macaranga aleuritoides, dapat tumbuh pada setiap tingkatan meskipun tidak selalu menempati urutan INP terbaik. Jenis Mallotus sp merupakan jenis yang selalu menempati INP terbaik dan hadir pada setiap tingkatan. Indeks keragaman jenis pada tingkat tiang tergolong rendah yaitu 0.61. Keragaman jenis yang rendah ini berhubungan dengan masa bera lahan yaitu 5 tahun. Pada masa tersebut, jumlah jenis dan keragaman yang ada masih tergolong rendah. Secara periodik, perubahan akan terjadi dalam masa suksesi, dengan adanya penambahan jenis, densitas dari masingmasing individu, tinggi tumbuhan, dan struktur komunitas yang akan berkembang secara kompleks. Supriyadi (2008) menyatakan, peningkatan struktur dan fisik tanah merupakan salah satu mekanisme meningkatnya bahan organik yang berimplikasi pada peningkatan hasil perkebunan. Tingkat Tiang merupakan bagian penting pada suatu komunitas di lahan bera 5 tahun, karena fase ini jenis yang tumbuh akan berkembang mejadi tingkat pohon. Selain itu, tutupan tajuk fase ini sangat penting menunjang iklim mikro dan tajuk yang memberi perlindungan bagi tumbuhan yang ada di bawahnya.

Inventarisasi lain yang dilakukan untuk menganalisis dampak vegetasi terhadap kesuburan tanah adalah jenis tumbuhan penutup tanah. Jumlah jenis tumbuhan penutup tanah pada lahan bera 5 tahun ada 61 jenis. Fungsi tumbuhan penutup tanah pada lahan suksesi adalah untuk memperbaiki kualitas tanah (sifat fisik dan kimia tanah), menekan pertumbuhan gulma, dan memperkaya 
kandungan $\mathrm{N}$ dalam tanah. Jenis-jenis yang berperan paling besar dalam akumulasi kandungan $\mathrm{N}$ dalam tanah meningkatkan kesuburan tanah yang mampu merubah struktur dan jenis alami pada tahap suksesi awal di lahan bera. Kondisi ini sangat menentukan bagi pubescens mampu membentuk lapisan tumbuhan bawah yang cukup rapat. Lapisan tersebut berfungsi membuat naungan yang sangat berguna bagi perkembangan jenis pioner awal sehingga menghasilkan kerapatan individu tinggi. Jenis tumbuhan penutup tanah lainnya yang ditemui di lahan bera 5 tahun adalah Poeraria repens. Jenis ini menurut Azwar (2015) sangat efektif dalam penambatan unsur N. Penambatan unsur N pada tanah sangat penting sebagai penambah unsur utama bagi kesuburan tanah. Jenis Alocasia macoriza juga digunakan oleh suku Arfak sebagai indikator kesuburan tanah pada lahan bera. Peningkatan jumlah pada jenis tersebut menandakan dimulainya pemanfaatan kembali lahan yang telah diberakan.

\section{Kebun Aktif}

Areal kebun aktif Ayambori merupakan areal yang digunakan oleh masyarakat untuk tanaman perkebunan. Jenis-jenis yang ada di perkebunan adalah Centrosema pubescens. Prayudyaningsih et al (2015) menyatakan, Centrosema pubescens dapat peningkatan kekayaan dan keanekaragaman jenis pada semua tingkat habitus jenis tumbuhan secara alami yang tumbuh secara spontan. Jenis Centrosema masyarakat terdiri dari berbagai jenis tanaman perkebunan yang ditanam. Lokasi kebun yang ditanami tersebut letaknya tidak jauh dari rumah. Masyarakat umumnya tidak mengelola dengan metode tertentu karena keterbatasan pengetahuan dan keterampilan. Secara umum masyarakat hanya membiarkannya secara alami dan membersihkan sebagian lahan perkebunan dari gulma jenis rumputrumputan.

Tingkat vegetasi di kebun aktif kampung Ayambori terdiri dari semai, pancang, tiang, dan pohon. Tingkat semai mempunyai jumlah 39 jenis dengan 264 individu, tingkat pancang 36 jenis dengan jumlah individu 221, tingkat tiang 16 jenis dengan jumlah individu 94, dan tingkat pohon 17 jenis dengan jumlah individu 92. Komposisi jenis tingkat semai dengan urutan INP dapat dilihat pada Tabel 4. 
Tabel 4. Indeks Nilai penting jenis Tingkat Semai pada Kebun Aktif

\begin{tabular}{rlccc}
\hline No & \multicolumn{1}{c}{ Nama Jenis } & KR & FR & INP \\
\hline 1. & Nephelium lappaceum & $9.09 \%$ & $7.50 \%$ & $16.59 \%$ \\
\hline 2. & Premna corymbosa & $7.20 \%$ & $7.50 \%$ & $14.70 \%$ \\
\hline 3. & Macaranga aleutoides & $7.20 \%$ & $5.00 \%$ & $12.20 \%$ \\
\hline 4. & Artocarpus altilis & $5.30 \%$ & $5.83 \%$ & $11.14 \%$ \\
\hline 5. & Kleinhovia hospital & $6.06 \%$ & $5.00 \%$ & $11.06 \%$ \\
\hline 6. & Ficus septica & $3.79 \%$ & $6.67 \%$ & $10.45 \%$ \\
\hline 7. & Macaranga mappa & $4.55 \%$ & $5.83 \%$ & $10.38 \%$ \\
\hline 8. & Mallotus sp. & $5.30 \%$ & $5.00 \%$ & $5.30 \%$ \\
\hline 9. & Theobroma cacao & $3.79 \%$ & $5.00 \%$ & $8.79 \%$ \\
\hline 10. & Ficus trachypison & $3.41 \%$ & $3.33 \%$ & $6.74 \%$
\end{tabular}

Jenis dominan pada tingkat semai adalah Nephelium lappaceum dengan nilai INP $16.59 \%$, disusul masing-masing oleh jenis Premna corymbosa $14.70 \%$ dan Macaranga aleutoides $12.20 \%$. Tingkat semai yang memiliki potensi ekonomi sebagai tanaman perkebunan antara lain Nephelium lappaceum dan Theobroma cacao yang masuk dalam daftar INP terbaik, sedangkan jenis Durio zibentinus, Lansium domesticum, dan Mangifera indica merupakan jenis yang tidak masuk dalam peringkat INP terbaik. Jenis tersebut sengaja ditanam oleh masyarakat di areal perkebunan dengan harapan dapat dipanen dan dijual pada musim buah tiba. Jumlah individu tingkat semai lebih banyak dibandingkan dengan fase lainnya di kebun aktif. Banyaknya individu di kebun aktif berjumlah 264 individu. Jumlah tersebut lebih banyak dibandingkan dengan fase semai di lahan bera 5 tahun. Kondisi tersebut disebabkan karena tutupan kanopi pohon yang lebar sehingga suhu menjadi rendah, kelembaban tinggi, dan intensitas cahaya rendah. Keadaan ini menciptakan iklim mikro yang menunjang bagi pertumbuhan fase semai. Indeks keragaman jenis tingkat semai berkategori sedang 1.43. keragaman jenis ini memiliki hubungan dengan jumlah individu masingmasing jenis. Semakin tinggi jumlah individu jenis makin tinggi juga keragamannya.

Komposisi kebun campur yang banyak ditumbuhi pepohonan, mempengaruhi keberadaan unsur tanah. Sumbangan bahan organik yang berasal dari serasah dibutuhkan oleh ekosistem tanah yang berfungsi sebagai sumber pengikat hara dan substrat bagi mikroba tanah. Keberadaan semai yang tumbuh di 
bawah tegakan pohon juga berfungsi tanah dari tumbukan air hujan secara langsung. Peranan ini sangat penting, mengingat tenaga air hujan dapat merusak agregat tanah. Olehnya keberadaan semai mampu memperbaiki kesuburan tanah secara fisik, kimiawi maupun secara biologi.

Komposisi jenis tingkat Pancang jumlah seluruhnya 36 jenis, dengan total individu Seluruh jenis 221 individu. Jenis yang mendominasi urutan 10 INP terbaik adalah jenis tumbuhan buah seperti Nephelium lappaceum, Lansium domesticum, Theobroma cacao, dan Durio zibentinus, jenis-jenis tersebut selain tumbuh secara sebagai penutup tanah dan melindungi alami juga sebagian ditanam oleh pemilik kebun. Selain jenis tersebut terdapat jenis buah yang tumbuh secara alami seperti Pometia pinnata. Jenis tersebut merupakan endemik Papua dan kayunya memiliki nilai komersial. Jenis tumbuhan buah lainnya yang tidak masuk dalam daftar INP terbaik antara lain Artocarpus heteropilus, Artocarpus integra, dan Mangifera indica. Secara lengkap komposisi jenis tingkat pancang dapat dilihat pada Tabel 5.

Tabel 5. Indeks Nilai Penting Jenis Tingkat Pancang di Kebun Aktif

\begin{tabular}{rlrrr}
\hline No & \multicolumn{1}{c}{ Nama Jenis } & \multicolumn{1}{c}{ KR } & \multicolumn{1}{c}{ FR } & \multicolumn{1}{c}{ INP } \\
\hline 1. & Nephelium lappaceum & $10.86 \%$ & $10.34 \%$ & $21.20 \%$ \\
\hline 2. & Lansium domesticum & $9.50 \%$ & $8.62 \%$ & $18.12 \%$ \\
\hline 3. & Theobroma cacao & $9.50 \%$ & $7.76 \%$ & $17.26 \%$ \\
\hline 4. & Gliricidia sepium & $9.50 \%$ & $6.90 \%$ & $16.40 \%$ \\
\hline 5. & Kleinhovia hospita & $7.69 \%$ & $6.03 \%$ & $13.73 \%$ \\
\hline 6. & Durio zibentinus & $5.88 \%$ & $7.76 \%$ & $13.64 \%$ \\
\hline 7. & Pometia pinnata & $6.33 \%$ & $6.03 \%$ & $12.37 \%$ \\
\hline 8. & Premna corymbosa & $6.33 \%$ & $6.03 \%$ & $12.37 \%$ \\
\hline 9. & Artocarpus altilis & $4.98 \%$ & $5.17 \%$ & $10.15 \%$ \\
\hline 10. & Ficus septica & $3.62 \%$ & $4.31 \%$ & $7.93 \%$
\end{tabular}


Indeks keragaman jenis tingkat pancang tergolong sedang dengan nilai 1.31 dengan indeks kemerataan jenis juga tergolong sedang yaitu 0.37. Keragaman jenis tersebut bisa jadi diakibatkan karena campur tangan manusia dalam komunitas vegetasi. Jumlah jenis tertentu seperti Nephelium lappaceum, lansium domesticum, Theobroma cacao, Durio zibentinus, Artocarpus heteropilus, Artocarpus integra, dan Mangifera indica, merupakan jenis unggulan yang ditanam turut berkontribusi dalam penambahan jumlah dan individu jenis. Saat perkembangannya, jenis yang beregenerasi cukup baik di masa yang akan datang akan menggantikan posisi jenis utama. seluruh jenis yang ditemukan terdapat $68.75 \%$ jenis pohon buah potensial. Jumlah individu terbanyak pada tingkatan ini adalah Lansium domesticum dan Nephelium lappaceum. Adapun jenis lainnya yang ditemukan antara lain Annona muricata, Arthocarpus
Keragaman di kebun aktif masyarakat juga dipengaruhi oleh hilangnya jenis-jenis asli yang ada dilokasi perkebunan, karena biasanya hanya jenis unggulan yang ditanam. Ripin et al (2012) menyatakan bahwa jenis tumbuhan di areal perkebunan memiliki syarat tertentu untuk tumbuh, seperti tanah dengan kapasitas meneruskan kelebihan air, tanah yang gembur, dan pengaruh tutupan tajuk. Kondisi lingkungan di lokasi penelitian menunjang pertumbuhan jenis dan berpengaruh pada jumlah individu.

Komposisi jenis tiang di lahan perkebunan aktif di kampung Ayambori seluruhnya berjumlah 16 jenis dengan total individu sebanyak 94 individu. Dari heterophillus, Arthocarpus integra, Citrus sp., Durio zinbentinus, Pometia pinnata, Theobroma cacao, dan Spondias cyterea. Selengkapnya susunan jenis yang menempati INP 10 terbaik dapat disajikan pada Tabel 6. 
Tabel 6. Indeks Nilai Penting Jenis Tingkat Tiang di Lahan Kebun Aktif Ayambori

\begin{tabular}{rlrrrr}
\hline \multicolumn{1}{c}{ No } & \multicolumn{1}{c}{ Nama Jenis } & KR & FR & DR & \multicolumn{1}{c}{ INP } \\
\hline 1. & Lansium domesticum & $32.98 \%$ & $18.18 \%$ & $30.03 \%$ & $81.19 \%$ \\
\hline 2. & Nephelium lappaceum & $14.89 \%$ & $14.55 \%$ & $16.07 \%$ & $45.51 \%$ \\
\hline 3. & Theobroma cacao & $10.64 \%$ & $10.91 \%$ & $11.25 \%$ & $32.80 \%$ \\
\hline 4. & Artocarpus heteropilus & $7.45 \%$ & $9.09 \%$ & $9.30 \%$ & $25.84 \%$ \\
\hline 5. & Durio zibenthinus & $7.45 \%$ & $9.09 \%$ & $7.03 \%$ & $23.57 \%$ \\
\hline 6. & Pometia pinnata & $5.32 \%$ & $9.09 \%$ & $3.66 \%$ & $18.07 \%$ \\
\hline 7. & Mangifera indica & $3.19 \%$ & $5.45 \%$ & $5.08 \%$ & $13.72 \%$ \\
\hline 8. & Artocarpus integra & $3.19 \%$ & $5.45 \%$ & $3.16 \%$ & $11.80 \%$ \\
\hline 9. & Spondias cyterea & $3.19 \%$ & $3.64 \%$ & $2.12 \%$ & $8.95 \%$ \\
\hline 10. & Gliricidia sepium & $3.19 \%$ & $3.64 \%$ & $1.86 \%$ & $8.69 \%$ \\
\hline & & & & &
\end{tabular}

Indeks keragaman jenis tingkat tiang di lokasi kebun aktif rendah yaitu 0.97, hal ini disebabkan karena faktor manusia yang lebih dominan. Manusia lebih banyak melakukan seleksi terhadap keberadaan jenis yang tumbuh di Lokasi kebun aktif. Jenis yang dianggap tidak berguna bagi kepentingan ekonomi akan ditebang. Meskipun demikian, Indeks kemerataan Jenis termasuk sedang yaitu
0.34. Hal ini membuktikan bahwa setiap jenis tersebar merata dalam setiap petak pengamatan.

Komposisi jenis tingkat pohon di lokasi kebun aktif Ayambori seluruhnya 17 jenis dengan jumlah Seluruh individu sebanyak 55 individu. Selengkapnya urutan 10 INP terbaik tingkat tiang dapat dilihat pada Tabel 7.

Tabel 7. Indeks Nilai Penting Jenis Tingkat Pohon di Lokasi Kebun Aktif Ayambori

\begin{tabular}{rlrrrr}
\hline No & \multicolumn{1}{c}{ Nama Jenis } & \multicolumn{1}{c}{ KR } & FR & DR & \multicolumn{1}{c}{ INP } \\
\hline 1. & Durio zibenthinus & $20 \%$ & $28.26 \%$ & $48.31 \%$ & $96.57 \%$ \\
\hline 2. & Nephelium lappaceum & $20 \%$ & $28.26 \%$ & $19.07 \%$ & $67.33 \%$ \\
\hline 3. & Artocarpus heteropilus & $14.55 \%$ & $11.96 \%$ & $5.87 \%$ & $32.38 \%$ \\
\hline 4. & Lansium domesticum & $7.27 \%$ & $7.61 \%$ & $3.19 \%$ & $18.07 \%$ \\
\hline 5. & Kleinhovia hospita & $5.45 \%$ & $4.35 \%$ & $2.34 \%$ & $12.14 \%$ \\
\hline 6. & Artocarpus altilis & $3.64 \%$ & $2.17 \%$ & $4.77 \%$ & $10.58 \%$ \\
\hline 7. & Persea americana & $5.45 \%$ & $3.26 \%$ & $1.63 \%$ & $10.35 \%$ \\
\hline 8. & Dysoxylum mollissimum & $3.64 \%$ & $2.17 \%$ & $3.73 \%$ & $9.54 \%$ \\
\hline 9. & Sterculia arceolata & $3.64 \%$ & $2.17 \%$ & $3.41 \%$ & $9.22 \%$ \\
\hline 10. & Pometia pinnata & $3.64 \%$ & $2.17 \%$ & $3.30 \%$ & $9.11 \%$
\end{tabular}


Pohon memiliki kontribusi penting terhadap tanah, khususnya sumbangsihnya terhadap kesuburan. Ciri morfologi tertentu pada jenis pohon turut mempengaruhi distribusi air yang jatuh di atas tanah. Budirianto (2011) menyatakan, bentuk percabangan tertentu dapat memberikan dampak yang baik bagi infiltrasi air ke dalam tanah. Proses tersebut dapat memberikan peningkatan terhadap kadar air tanah serta memberikan kelembaban pada tanah yang dapat memacu aktivitas mikroorganisme. Jenis pohon Durio zibentinus mempunyai model arsitektur yang mampu meningkatkan penyerapan air air lebih tinggi karena aliran air batang dapat meningkatkan kadar air tanah. Selain itu, sistem perakaran yang besar sangat berguna memecah agregat tanah sehingga menyebabkan poripori tanah lebih terbuka. Kumalasari (2011) et al menyatakan bahwa pertumbuhan diameter akar yang berukuran besar mampu menekan poripori tanah sehingga pori tanah akan membesar. Hal ini berdampak pada meningkatnya porositas tanah terhadap air.

$$
\text { Mindawati et al (2006) }
$$
menyatakan, dampak jenis dominan dapat memberikan dampak tertentu pada tanah. Kondisi ini juga berpengaruh pada sifat Biologi tanah. Sifat biologi memiliki hubungan dengan respirasi tanah yang mempengaruhi aktivitas mikroorganisme dan berdamapak pada pertumbuhan tanaman. Prihastuti (2011) menyatakan bahwa sifat biologis tanah merupakan substansi yang bersifat hidup, dinamis, dan mengalami perubahan pada ruang dan waktu. Kondisi ini memberikan peluang besar untuk pengelolaan tanah untuk memberikan peringatan dini adanya degradasi tanah, sehingga bisa direncanakan pengelolaan tanah yang berkelanjutan.

\section{KESIMPULAN}

1. Keragaman jenis vegetasi Kebun aktif lebih tinggi dibandingkan dengan Lahan Bera 5 tahun dari Jumlah jenis, banyaknya Individu seluruh fase dan Nilai Indeks Keragaman Jenis.

2. Aspek kesuburan tanah di lahan bera 5 tahun dan kebun aktif mengalami perkembangan yang dinamis. Hal ini ditunjukkan oleh banyaknya jumlah jenis dan individu di masing-masing lahan.

3. Jenis C. Pubescens, P. repens, dan $A$. macoriza dapat dijadikan petunjuk indikator kesuburan tanah. Jenis-jenis tersebut tidak dikenal oleh masyarakat, karena Masyarakat Kampung Ayambori menjadikan banyaknya jenis dan 
individu sebagai indikator kesuburan tanah.

\section{DAFTAR PUSTAKA}

Ainillah, RG. 2011. Korelasi Arsitektur Pohon Model Rauh dari Jenis Pinus merkusii Junghuhn \& de Vriese dengan Konservasi Tanah dan Air di Area PHBM yang Ditanami Coffea arabica L. RPH Gambung KPH Bandung Selatan. [Tesis]. Bogor: Program Pasca Sarjana, Institut Pertanian Bogor.

Arijani. 2006. Korelasi Model Arsitektur Pohon Dengan Laju Aliran Batang, Curahan Tajuk, Infiltrasi, Aliran Permukaan dan Erosi (Suatu studi tentang peranan vegetasi dalam konservasi tanah dan air pada subDAS Cianjur Cisokan Citarum Tengah) [Disertasi]. Bogor: Program Pasca Sarjana, Institut Pertanian Bogor.

Budirianto, H. 2012. Hubungan Model Arsitektur Pohon Roux Jenis Koordersiodendron pinnatum Merr dan Koriba Jenis Pometia pinnata Forster Terhadap Parameter Perimbangan Air di Hutan Tanaman Anggori Manokwari. Jurnal BioScience Vol. 1. No. 1: 12-22

Brearley FQ, Press MC, Scholes JD. 2003. Nutrients Obtained From Leaf Litter Can Improve The Growth OF Dipterocarp Seedlings. New Phytologist 160 : 101-110.

Fachrul M. 2007. Metode Sampling Bioekologi. Bumi aksara. Indonesia.

Halle F, RAA Oldeman, Tomlison PB. 1978. Tropical Trees and Forest an Architecture Analysis. New York: Springer-Verlag.

Kasim S. 2012. Nilai Penting Dan Keanekaragaman Hayati Hutan Lindung Wakonti Das Baubau. Jurnal Agriplus. Vol. 22 No. 2.

Kurniasari S. 2009. Produktivitas Serasah dan Laju Dekomposisi Di Kebun Campur Senjoyo Semarang Jawa Tengah Serta Uji Laboratorium Anakan Mahoni (Swietenia macrophylla King) Pada Beragam Dosis Kompos Yang Di Campur EM4. [Tesis]. Bogor: Program Pasca Sarjana, Institut Pertanian Bogor.

Kumalasari SW, Syamsiah J, Sumarno. 2011. Studi Beberapa Sifat Fisika Dan Kimia Tanah Pada Berbagai Komposisi Tegakan Tanaman Di Sub Das Solo Hulu. Jurnal Ilmiah Ilmu Tanah dan Agriklimatologi $8(2)$.

Murniati. 2010. Arsitektur Pohon, Distribusi Perakaran, Dan Pendugaan Biomassa Pohon Dalam Sistem Agroforestri. Jurnal Penelitian Hutan dan Konservasi Alam Vol. 7 No.2: 103-117

Mindawati N, Kosasih AS, Heryati Y. 2006. Pengaruh Penanaman Beberapa Jenis Pohon Hutan Terhadap Kondisi Kesuburan Tanah Andosol. Jurnal Penelitian Hutan Tanaman Vol 3. No. 3. Juni 2006 : 155-164.

Oksana, Irfan M, Huda MU. 2012. Pengaruh Fungsi Alih Lahan HutanMenjadi Perkebunan Kelapa Sawit Terhadap Sifat Kimia Tanah. 
Jurnal Agroteknologi Vol. 3 No.

Prihastuti. 2011. Struktur Komunitas Mikroba Tanah dan Implikasinya Dalam Mewujudkan Sistem Pertanian berkelanjutan. Jurnal El hayah. Vol. 1. No 4. Maret 2011 :174-181.

Soewandita H. 2008. Studi Kesuburan Tanah dan Analisis Kesesuaian Lahan Untuk Komoditas Tanaman Perkebunan Di Kabupaten Bengkalis. Jurnal Sains dan Teknologi Indonesia Vol. 10 No 2:128-133.

Suprayogo D, Widianto, Purnomosidi P, Widodo RH, Rusiana F, Zauhara ZA, Khasanah N, Kusuma Z. 2007. Degradasi Sifat Fisik Tanah Sebagai Akibat Alih Guna Lahan Hutan Menjadi Sistem Kopi Monokultur: Kajian Perubahan Makroporositas Tanah. Jurnal Agronomi Vol. 30 No. 2: 31-38.
1:29-34

Supriyadi S. 2008. Kandungan Bahan Organik Sebagai Dasar Pengelolaan Tanah di Lahan Kering Madura. Jurnal Embryo Vol. 5. No. 2: 176183

Umam, NR. 2011. Hubungan Model Arsitektur Massart dari Pohon Agathis dammara L.C.Richard dengan Konservasi Tanah dan Air di RPH Gambung Petak 27 Area PHBM, KPH Bandung Selatan. [Tesis]. Bogor: Program Pasca Sarjana, Institut Pertanian Bogor.

Yamani A. 2010. Kajian Tingkat Kesuburan Tanah Pada Hutan Lindung Gunung Sebatung di Kabupaten Kota Baru Kalimantan Selatan. Jurnal Hutan Tropis Vol. 11 No 29:32-37

Yuwono, NW. 2009. Membangun Kesuburan Tanah Di Lahan Marginal. Jurnal Ilmu Tanah dan Lingkungan. Vol. 9. No. 2. P: 137141 